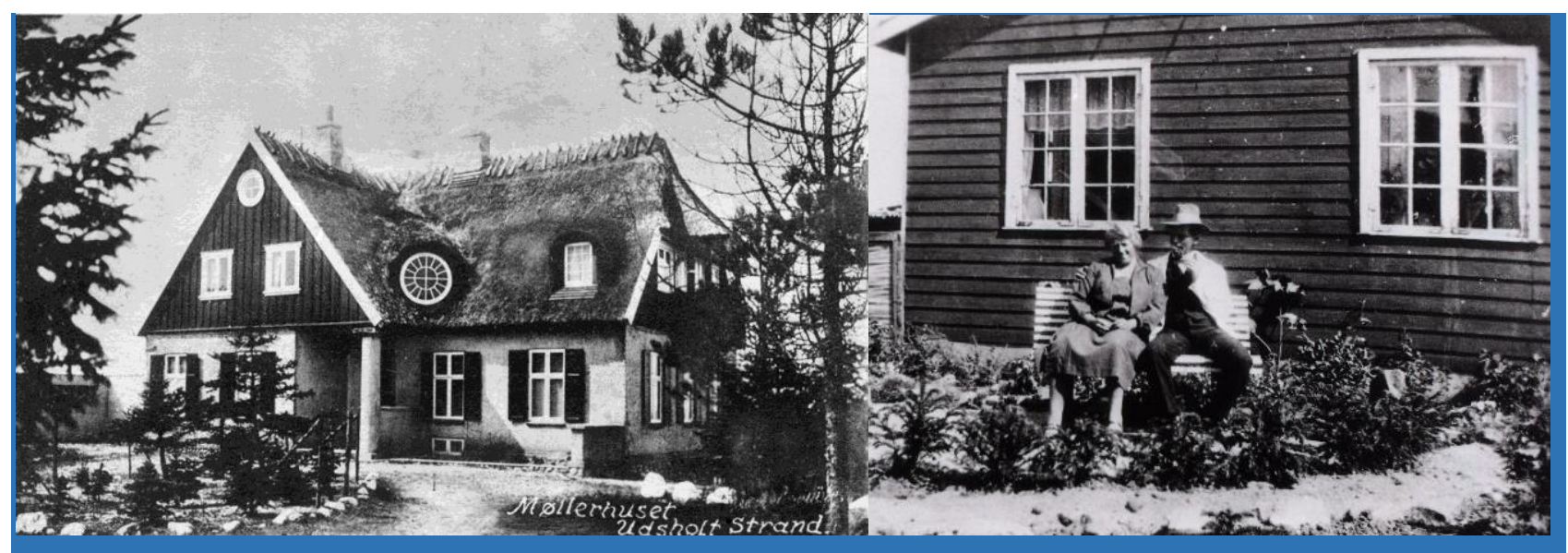

Henning Bro

\title{
Sommerhusbyen
}

Sommerhusbyer i mellem- og efterkrigstidens hovedstadsmetropol

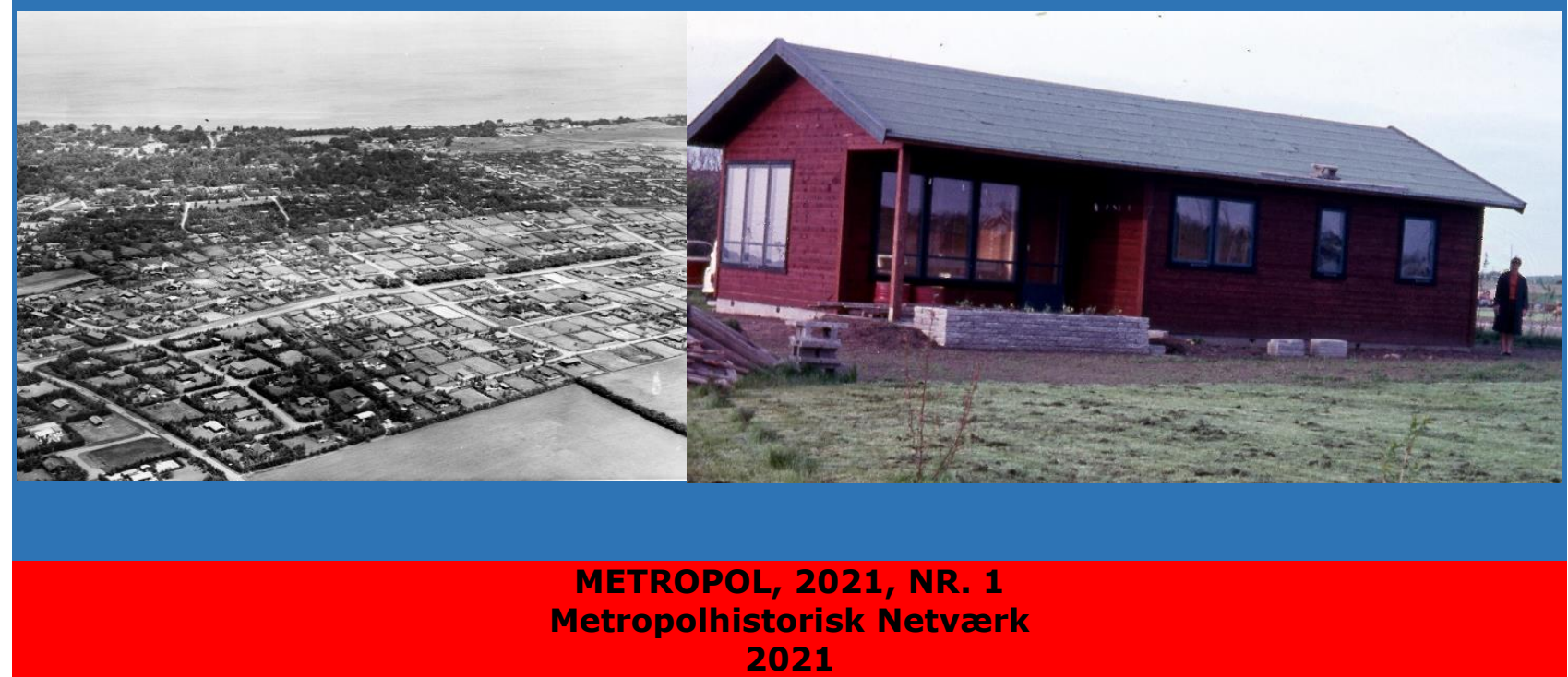




\section{DEL I}

De historiske forudsætninger 


\section{Kapitel 1}

\section{Sommerslotte- og landsteder: Tiden før 1850}

I århundreder var arbejdsfri tid ukendt for feudalsamfundets fæstebønder og de førindustrielle byers arbejder og håndværker og en del af livets muligheder, som kun provinsens godsejere, hoffet og det højest placerede borgerskab i København var begunstiget med. En fritid, der udlevedes i gemakker på hovedgårdene eller i prægtige kongelige slotte og borgerpalæer i København, men som i sommerperioden af samme absolutte minoritet henlagdes uden for den stadig større og mere fortættede by, som hovedstaden netop udviklede sig til i løbet af 1600tallet og gennem de følgende århundreder.

\section{Det danske imperiums centrum}

Selv om København blev hovedstad i senmiddelalderen og samtidig landets største købstad, blev det først med de omfattende udvidelser og befæstninger i løbet af det 17 . århundrede, at byen rykkede op som landets helt dominerende centralby. En position, som forstærkedes op gennem den sidste del af århundredet, i 1700-tallet og den første del af det 19. århundrede som følge af Københavns stilling som hovedstad i det tilbageværende danske imperium, enevoldstatens magtcentrum, hjemsted for merkantilismens manufakturer og handelskompagnier og landets militære tyngdepunkt. En hovedstad, der i midten af det 19. århundrede med en befolkning på 130.000 indbyggere var blevet tolv gange større end landets næststørste by, Odense, og tegnede sig for 18 procent af Danmarks befolkning.

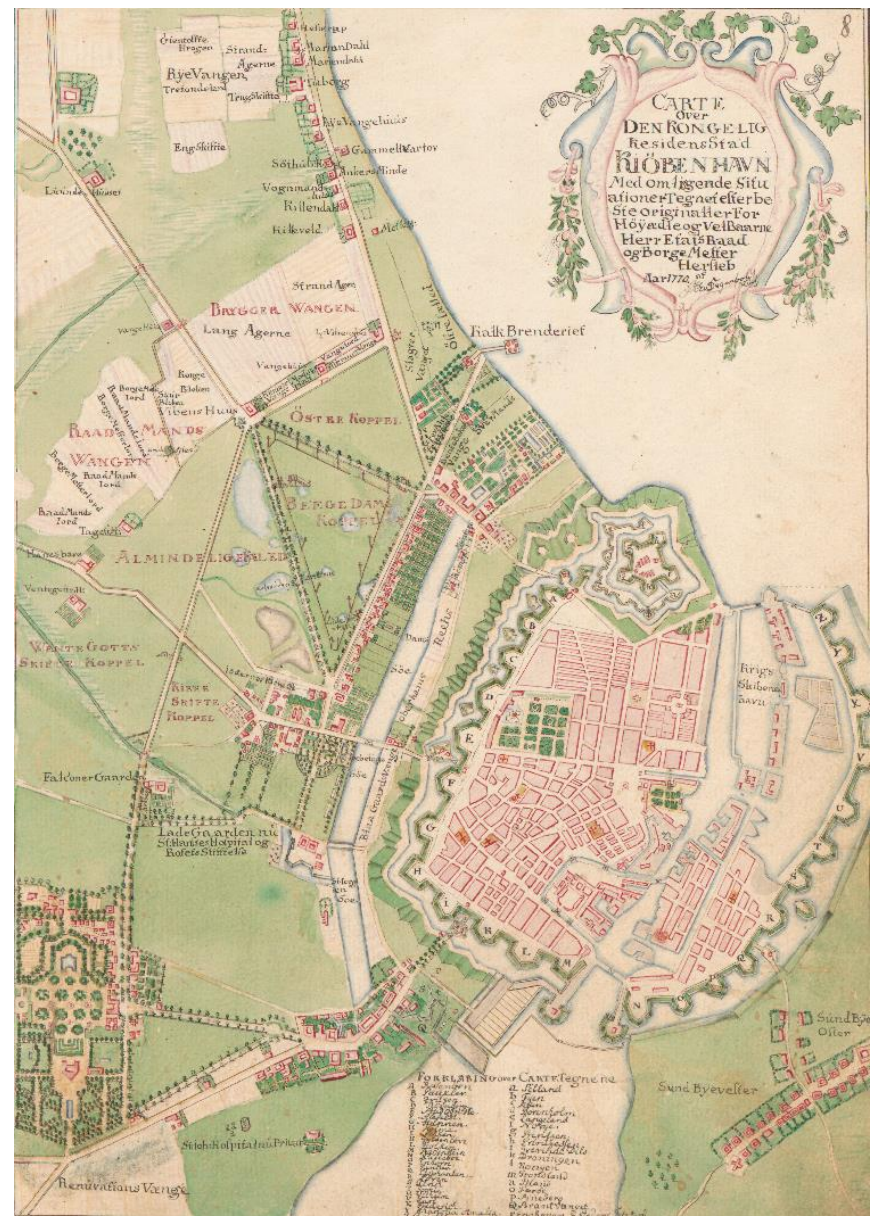

Det fæstningsindespærrede København, stadens uden for liggende grund på de senere brokvarterer samt nederst til venstre det selvstændige Frederiksberg Sogn med Frederiksberg by og sommerresidensslottet af samme navn. Kort 1770. (Københavns Stadsarkiv) 
Men også en hovedstad, der med sit volumen længe inden havde præget sit opland langt mere end købstæderne rundt om i landet. Allerede fra omkring år 1600 havde kronen anlagt kongeveje ud fra hovedstaden, og gennem den sidste halvdel af 1700 -tallet fulgte under ledelse af den indkaldte franske vejingeniør Jean Marmillod et nyt system af hovedveje som chausséer, der gik gennem hovedstadsoplandet og førte frem til Store Bælt, Kalundborg og Vordingborg. I kraft af den relativt korte afstand til København placeredes desuden størstedelen af merkantilismens store fabriksanlæg i Nordsjælland, og med den store befolkning genererede byen samtidig en stadig større specialisering i oplandets land- og skovbrug. Men hovedstadsopladet blev også et rekreations- og forlystelsesområde for det københavnske aristokrati og højborgerskab, når det om sommeren søgte ud af den beklumrede by. ${ }^{1}$

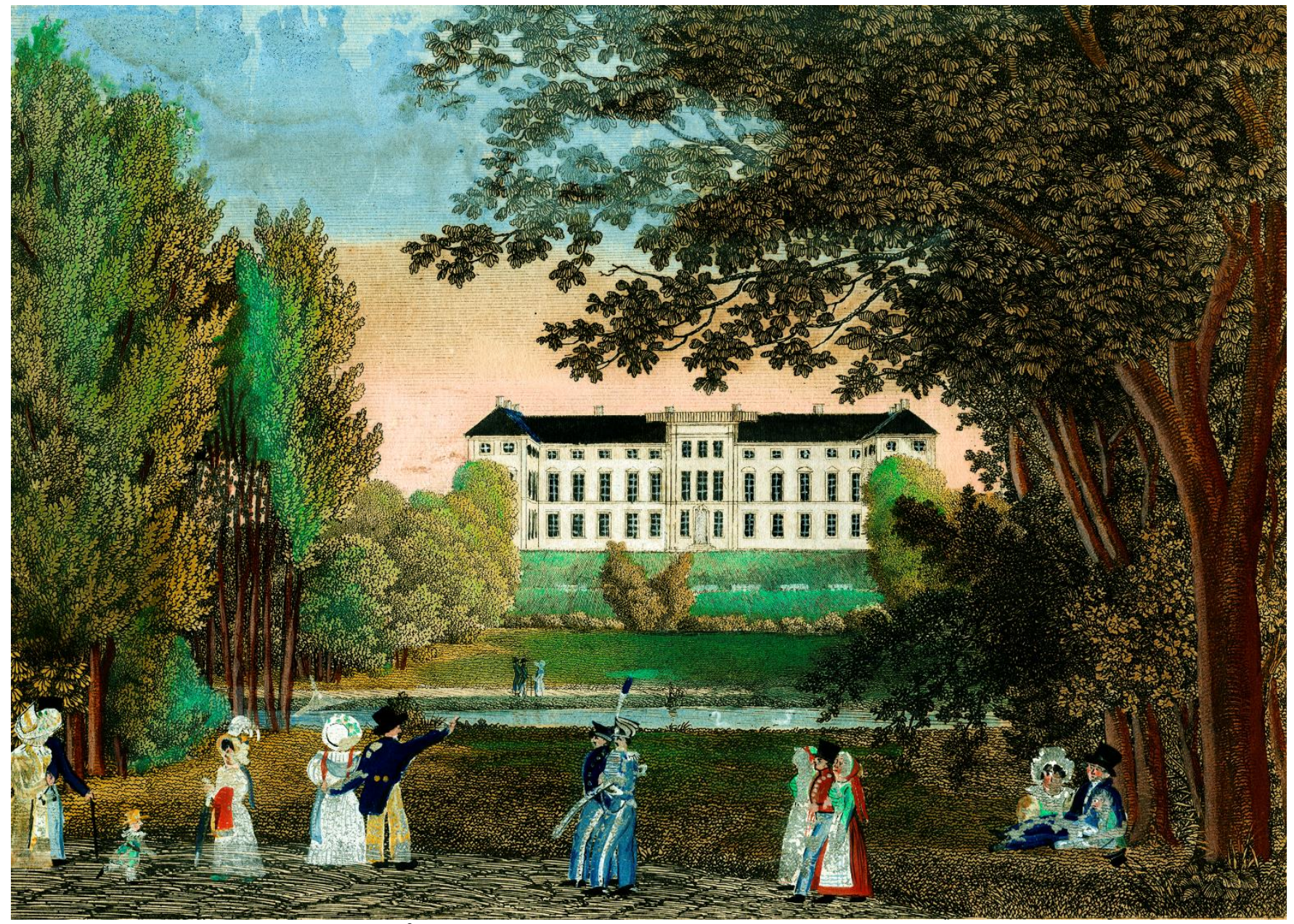

Frederiksberg Slot i starten af det 19. arhundrede, hvor de tidligere barokhaver nu var omlagt i engelsk romantisk havestil. (Frederiksberg Stadsarkiv)

\section{Aristokratiets rekreative opland}

Allerede i enevældens første årtier blev således en af fæstegårdene og dens tilliggender i landsbyen Ny Amager, senere Frederiksberg landsby, inddraget som sommerlandsted for kongefamiliens børn, og 1699 påbegyndte Frederik d. IV, inspireret af Versailles, opførelsen af den kongelige sommerresidens Frederiksberg Slot. Et anlæg, der op gennem de første årtiet af 1700-tallet kom til at omfatte et meget omfattende slotkompleks, staldgårde, funktionærboliger, gartnerier og mægtige slotshaver, hvortil den brede boulevard, Frederiksberg Allé, som en anden Avenue de Pais førte fra den krogede middelalderlige Roskildevej, som vor tids Vesterbrogade udgjorde. 
Men også længere ude i oplandet kom hoffet i hovedstaden til at øve sin indvirkning. Ved nedlæggelse af en hel landsby i Lyngby Sogn og inddragelse af yderligere arealer udlagdes allerede i 1670 Jægersborg Dyrehave og Hegn som store indhegnede områder for kongelig jagt, og på højdedraget med udsigt over Øresund opførtes jagtslottet Eremitagen i 1736. Tilsvarende anlagdes nye skove med jagtlinjer, bl.a. Hareskovene, til parforcejagt, ligesom området nord for Vejle $\AA$ udlagdes til kongelig vildtbane. Længere oppe i Nordsjælland var kirkegodset som andre stedet i landet ved reformationen overgået til kronen, der op gennem resten af 1500-tallet ved mageskifter sikrede, at det meste af Frederiksborg Amt blev krongods. Her blev de ældre kongelige herregårde, der lå nærmest hovedstaden, ombygget til nye land- og jagtslotte: Frederiksborg allerede lige efter år 1600 og Hirschholm i 1720 'erne. Og i samme årti kom det nye anlæg Fredensborg til.

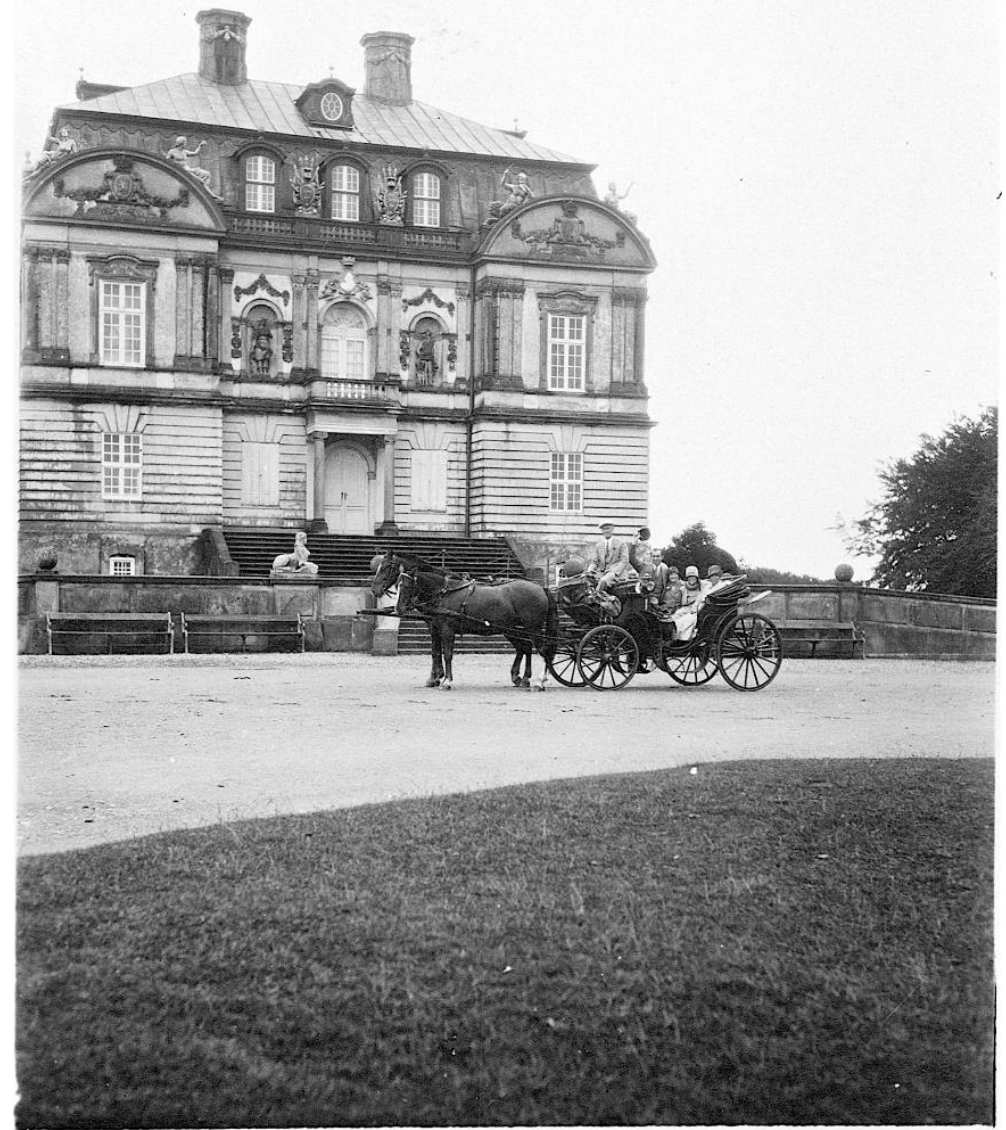

Eremitagen i Jægersborg Dyrehave en gang i 1930 'erne. Det lille jagtslot opførtes i 1736 (Københavns Museum)

Ikke kun for hoffet fik Nordsjællands smukke, skovrige og kuperede landskab betydning for rekreation og adspredelse. På samme tid som adelsfolk med gårde i København tog til hovedgårdene på provinsens godser, søgte hovedstadens højere borgerskab i første omgang ud til de bøndergårde, som til sommerophold var opkøbt eller lejet uden for byen. Men allerede fra slutningen af 1600-tallet og gennem de følgende 150 àr blev det stadig mere almindeligt i sommermănederne at tage længerevarende ophold i hovedstadsoplandet, hvor medlemmer af kongefamilien, industrialister, storkøbmænd, statens øverste embedsmænd og godsejere med palæer i København opførte egentlige landsteder. Prægtigst og størst blev de regulære slotskomplekser som Bernstorff (1767), Charlottenlund (1717) og Sorgenfri (1702), hvortil føjede sig et stort antal palælignende mindre landsteder med eller uden tilhørende landbrug, 
der blev drevet af forpagtere. Nogle opført i de sø- og kystnære naturskønne omgivelser i den nordlige del af Gladsaxe Sogn og ellers i Gentofte, Lyngby og Søllerød sogne. Andre tæt ved enevældens sommerresidens på Frederiksberg: I selve landsbyen, langs slotsalleen og på hele den nordlige halvdel af bymarken, som kronen satte på auktion i $1765 .^{2}$

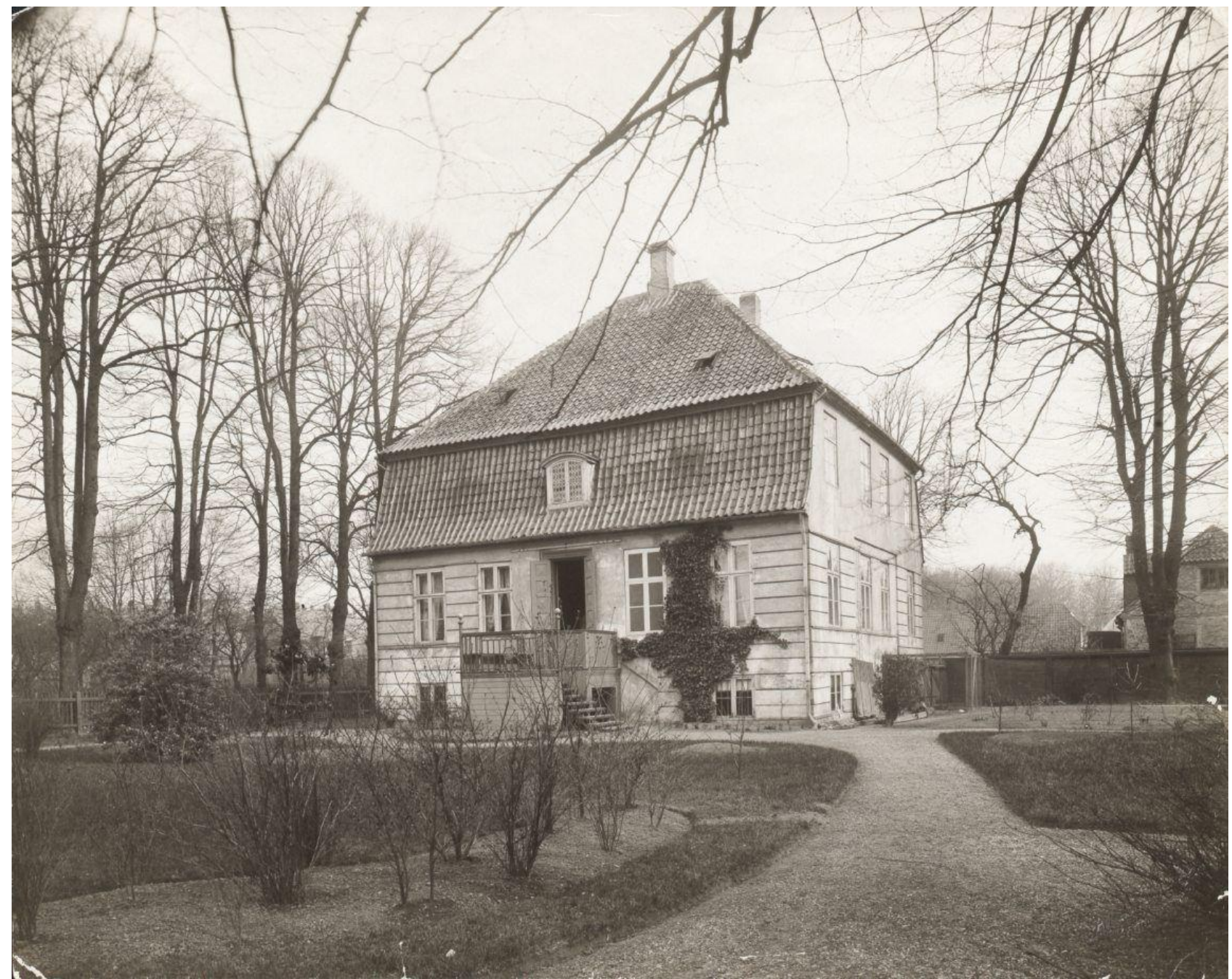

Landstedet Rolighed opførtes 1770 af den rige københavnske købmand C.A. Fabritius de Tengnagel på den nordlige del Frederiksberg bymark, der siden starten af arhundredet havde fungeret som hømark for de kongelige stalde $i$ København. Mens den sydlige del af hørarken, bymarken, i 1740'erne bliver givet i fæste til landsbyens gårdmænd, der 1775 overtog den del som selveje, blev hele den nordlige del, i forbindelsen med realiseringen af det kongelige domænegods, sat på auktion i 1765. På denne del opstod op gemme slutningen af 1700-tallet og ind i det nye århundrede en række sommerlandsteder for det københavnske storborgerskab. Foto ca. 1917 (Frederiksberg Stadsarkiv) 
Kapitel 2

\section{Sommervillabyer: 1850-1914}

Med industrikapitalismen gennembrud og videre udvikling i den sidste halvdel af det 19. århundrede og i de første tiår efter århundredskiftet, gereredes ikke blot en hidtil uset voldsom urbanisering både i hovedstaden og provisen, men også nye klassestrukturer. Kapitalejere og højtplacerede embedsmænd blev periodens nye overklasse, funktionærer et nyt mellemlag og fag- og ufaglærte arbejdere en stadig større underklasse. Med de nye klasser fulgte nye klasseforskelle, hvor løn- og arbejdsforhold og leve- og boligvilkår, men også ferie og fritidsliv og dermed et arbejdsfrit liv uden for den ekspanderende hovedstad blev nye parametre på tidens ulighed.

\section{Den fremvoksende hovedstadsmetropol}

Som følge af den begyndende industrialisering og en voldsom byfortætning sprængte København sig i 1852 ud af enevældens og den førindustrielle tids fæstningsværker, og hovedstaden bredte sig i de følgende årtier ind over dets umiddelbare opland. De københavnske broer skød op og udbyggedes, Frederiksberg forvandledes fra en landsby til en storby, og der begyndte at opstå bybebyggelser i de i København i 1901-1902 indlemmede distrikter og på de frederiksbergske vestlige yderdistrikter. Omkring udbruddet af første verdenskrig i 1914 havde København og Frederiksberg udviklet sig til en integreret hovedstad med et folketal på knap en halv million indbyggere, svarende til mere en fjerdedel af landets befolkning, og var samtidig blevet kerne i den hovedstadsmetropol, der omfattede villabyforstæder opstået længere ude i Hellerup, Charlottenlund, Klampenborg og Søborg.
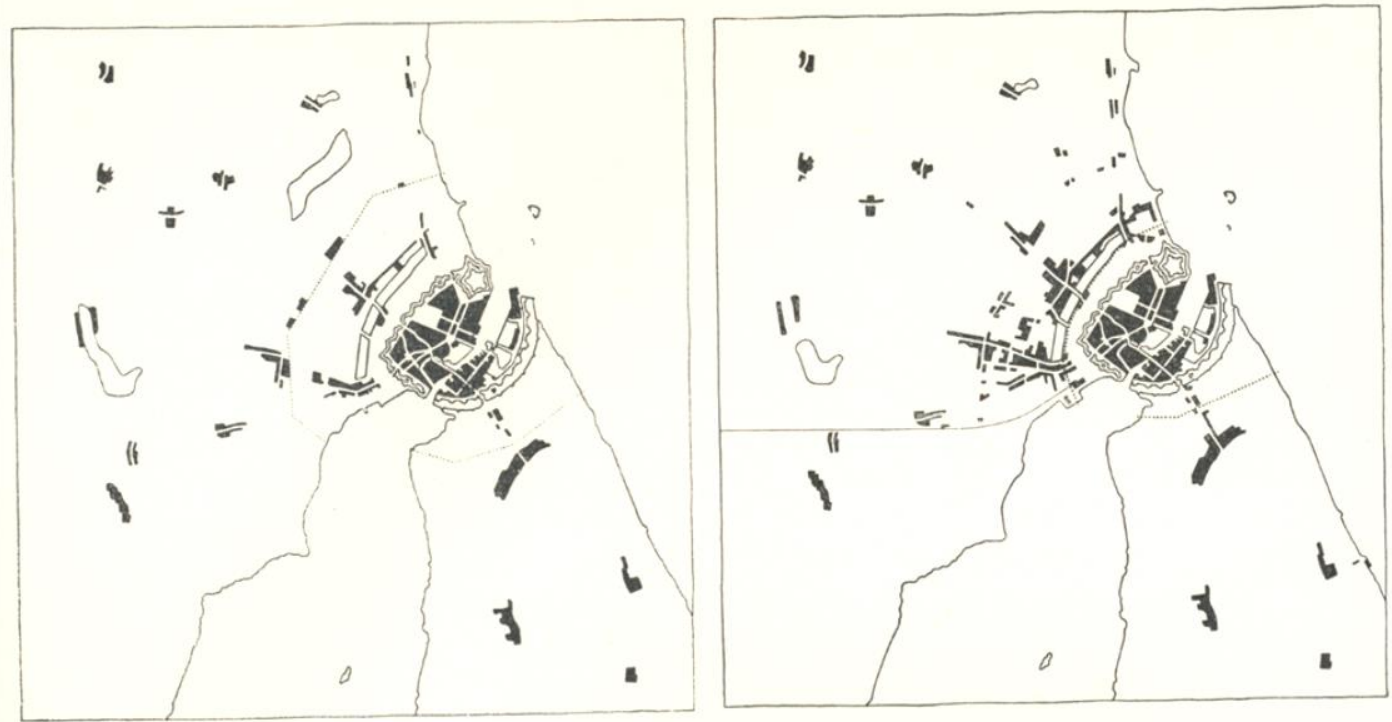

Hovedstadens bebyggelse. Til venstre: 1840. Til højre: 1860. (Holm og Johansen: København 1840-1940, 1940)

I den urbaniseringsproces afvikledes efterhånden ældre fabriksanlæg og boligområder i Københavns indre og tidligere førindustrielle bydel, der i stadig grad udviklede sig til et cityområde med specialiseret og eksklusiv detailhandel, landets centraladministration, videregående uddannelsesinstitutioner, kulturinstitutioner, hovedsæderne for banker, kreditforeninger, rederier, industrivirksomheder og interesseorganisationer samt en stribe af liberale erhverv. Inden for det stadig mere integrerede bysamfund, som København og Frederiksberg som hovedstad kom til at udgøre, kom Københavns indre by dermed indtil videre til at udgøre bysamfundets kerne, center, mens de københavnske brokvarterer og det 
østlige Frederiksberg, der fik sit eget bycentrum ved byens nye banegård, foreløbig blev dets periferi.

Hovedparten af centrets fabrikker og en betydelig del af dets af befolkningen, nyetablerede industrivirksomheder og den meget omfattende indvandring til hovedstaden blev således lokaliseret til periferien, hvor der var større friarealer og lavere grundpriser. De indre brokvartererne og det østlige Frederiksberg, der op mod århundredskiftet kom til at lægge sig som et første koncentrisk bylag uden om Københavns indre bydel, blev dermed i stadig højere grad tyngdepunktet for hovedstadens landsdækkende og regionalt orienterede industriproduktion, og leverede som boligområder samtidig arbejdskraften til både disse erhverv og dem, der forblev og voksede frem i cityområdet. En arbejdskraft, der fordeltes på boligområder, som omfattede både tæt, planløst bebyggede og erhvervsmæssigt stærkt opblandede industri- og arbejderkvarterer på indre Nørre- og Vesterbro og Frederiksberg, og villakvarter på andre dele af Frederiksberg og på det indre Østerbro

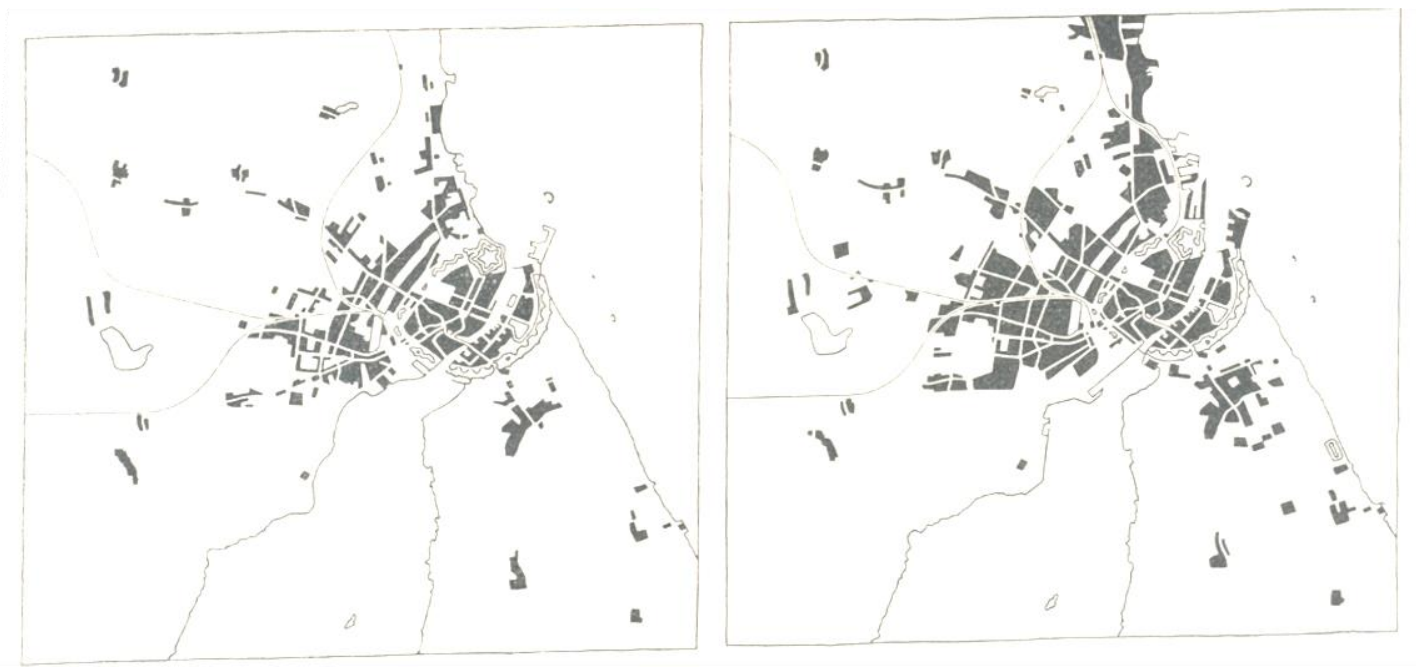

Hovedstadens bebyggelse. Til venstre: 1880. Til højre: 1900. (Holm og Johansen: København 1840-1940, 1940)

Med en forstærket by- og industritilvækst fulgte på de ydre broer og på Frederiksberg, frem til Fasanvejslinjen, i årtierne omring århundredeskiftet et andet og bredere koncentrisk bylag uden om det første med rene industrikvarterer i tilknytning til tidens nye havneanlæg og nye og planlagte jernbanelinjeføringer. Tæt ved de nye industrikvarterer, og som oftest i samme bydele, koncentreredes i samme bylag desuden kvarterer med boligkarrébebyggelser for arbejdere og lign. og nye villakvarterer for hovedstadens højeste indkomstlag. I et tredje koncentrisk bylag, der, i form af de i København i 1901-1902 indlemmende distrikter og de frederiksbergske yderdistrikter, på samme tid begyndte at lægge sig uden om det andet bylag, blev grunden samtidig lagt til meget store industriområder, ligesom der her opstod villakvarterer og mindre sammenhængende områder med andet etagebyggeri.

Mens både det andet og tredje bylag blev funktionelt integreret i den samlede hovedstad, blev de uden om liggende fremvoksende forstæder, på nær industrikvarteret ved Tuborg, foreløbig rene boligområder. Med denne proces forvandledes hovedstaden således som udstukket i Burgesse zoneteorie, jf. APPENDIX I.A., i tiden omkring århundredskiftet til en fremvoksende hovedstadsmetropol, der med interagerende funktionelt forskelligartede bynheder blev til en byregion med et center i Københavns indre by med offentlig og privat administrativ og service- og forretningsmæssig virksomhed, tre bylag med industri- og boligområder og udenom liggende boligforstæder. $^{3}$ 


\section{Fritid og friluftsliv - Et overklasseprivilegium}

Trods en vis nedsættelse af arbejdstiden via overenskomsterne forblev reel fritid til et godt stykke efter århundredskiftet ukendt for de brede samfundslag og særlig arbejderklassen. Dermed forsat et overklasseprivilegium, der i industrikapitalismens alt-dominerende fremvoksende hovedstadsmetropol og øvrige storbyer forbeholdtes tidens nye borgerskab af kapitalejere, grosserer, skibsredere og det højeste lag af embedsmænd i privat og offentlig virksomhed.

På nær mondæne lejligheder på visse dele af Frederiksberg og det københavnske Østerbro, dannede villaen i villakvarterne i sammen dele af hovedstaden rammen for dette borgerskabs daglige fritidsliv. Den villa, der i samtiden blev set som den mest ideelle ramme for industrisamfundets fremvoksende kernefamilie med den udarbejdende mand, den hjemmegående frue, børnene og eventuelle tjenestefolk, som de grundlæggende elementer. Med industrialismen nøje adskillelse mellem produktions- og arbejdsliv på fabrik eller kontor og på den anden side det uden for mere isolerede privat-, familie- og fritidsliv, fremstod kernefamilien som den mest trygge, idylliske, hyggeligste, kærligste og isolerede ramme, hvor man kunne opholde sig på afstand af det omgivende samfunds udfordringer. Værdier, der afspejlede sig i villaernes indretning som en enhed i form af stueetagen som kernefamiliens opholds- og samlingsbase med herreværelse, to eller flere stuer, soveværelser på førstesalen og med køkken og tilhørende pigeværelser mere adskilt fra "privaten" og dermed anbragt i kælderetagen eller $\mathrm{i}$ en anden og mere afsides del af villaen.

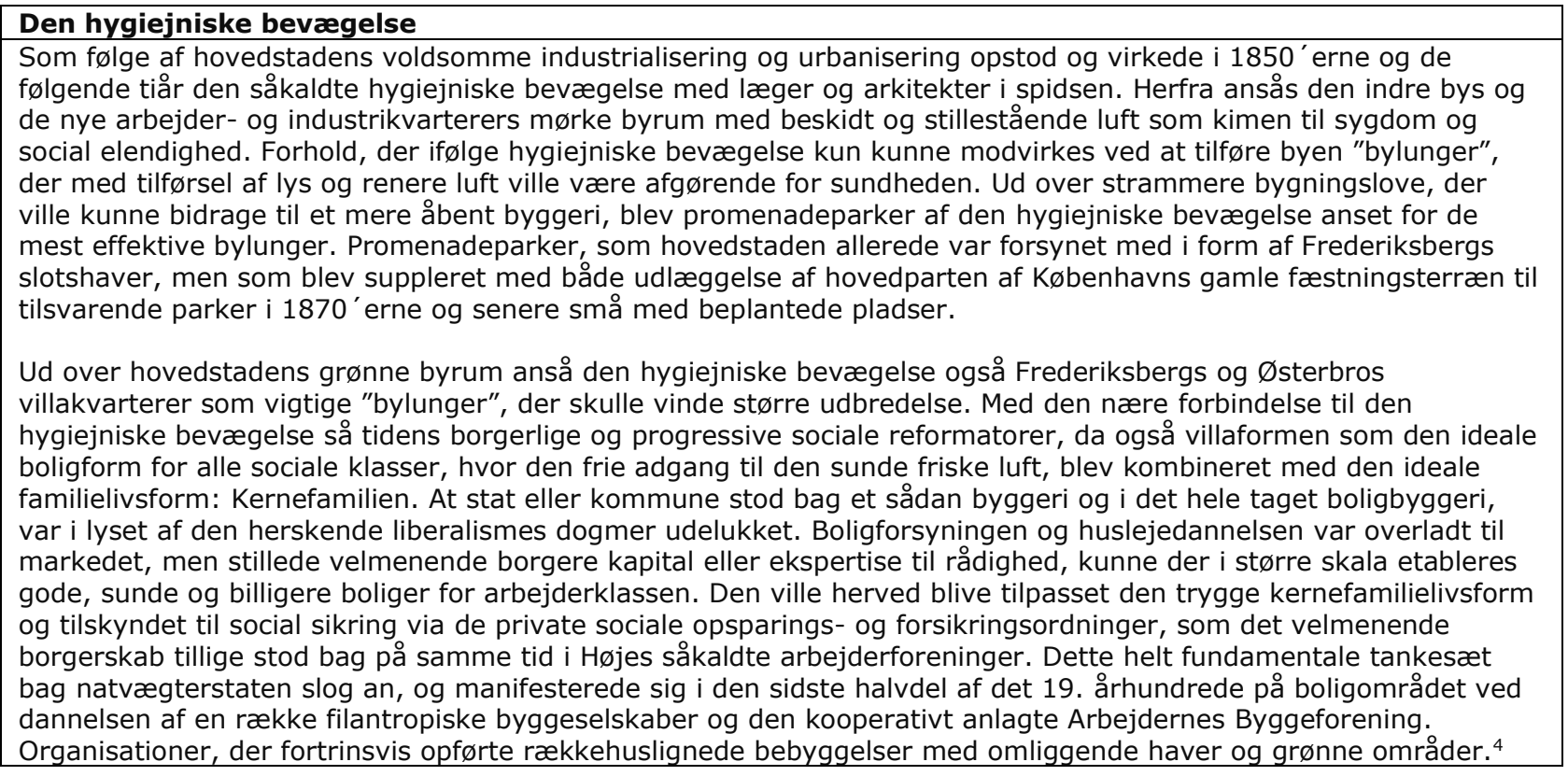

Med villaernes og de tilhørende havers nøje adskillelse af hække eller hegn understregedes samtidig kernefamiliens, efter tidens herskende liberalistiske ideologi nærmest ukrænkelige, privatsfære yderlige. Og med haven, havestuen og førstesalens balkoner signaleredes på samme tid ikke blot en ekstrem af velstand, men også, at villaernes beboerne i overensstemmelse med tidens hygiejniske tankegods også levede et godt og sundt fritidsliv langt fra den stadig mere fortættede hovedstads produktions- og arbejdsliv og overbyggede kvarterer, hvor lys og luft ikke trængte ind, og hvor den sociale elendighed trivedes; jf. tekstboks. Et idealliv, som borgerskabet i fritiden også supplerede med selskabelighed, deltagelse i hovedstadens kulturliv eller idræt- og friluftsliv sammen med ligestillede. Goder, der tillige var forbeholdt de mest velbjærgede. ${ }^{5}$

Når fritiden blev særlig lang i de ferieperioderne, som borgerskabet tillige var begunstiget med, henlagdes den til ophold på et badehotel, hvor den både fysiske og mentale afstand til den fortættede storby og dens produktions- og arbejdsliv var større og det sunde liv i naturen og ved kysterne kunne 
kombineres med selskabelighed med samme ligestillede. Tallige badehoteller opstod først på Fanø og Skagen, senere ved Nordsjællands Kattegatlyst og siden på mindre mondæne steder andre steder i landet. Samme ferieform kom tillige til at kendetegne de kursteder og badesanatorier, der opstod på samme tid for samme befolkningsgruppe.

Alle etablissementer placeret i naturskønne og kystnære omgivelser, hvor familien kunne placeres så længe børnene havde sommerferie, men som manden uden for dennes ferie måtte forlade for på hverdagene at passe sine vigtige forretninger i hovedstaden. Jernbanenettets udbygning og fra århundredskiftet automobilens stadig større udbredelse for de højeste indkomstlag muliggjorde denne ferieform. En ferieform, som det mere velstående lag af øvrige funktionærer og mere velbjærgede mindre selvstændig efterhånden forsøgte at efterstræbe ved at indlogere sig på sommerpensionater eller i fiskerlejernes småhuse, hvor fiskeren og hans familie flyttede ud i mere primitive udelænger for at supplere den beskedne indkomst med lejeindtægten.

Mens det solbrændte frem til midten af det 19.århundrede var udtryk for fæstebondens og senere selvejerens slidsomme arbejde i marken, og blegheden for godsejere og byborerskabets tilbagetrukne tilværelse på herregårde og borgerpalæer, ændredes ansigtskulørens statusgivende karakter efter industrialismens gennembrud fra tiden efter midten af det 19.århundrede. Bleghed blev nu et lavstatus fænomen og udtryk for et arbejdsliv, uden fritid, udlevet i mørke fabrikshaller eller i lukkede og snævre kontorlokaler og små lejligheder i hovedstadens industri- og arbejderkvarterer og andet fortættede etagebyggeri, mens solbrændthed blev eksponent for et liv med fritid og rekreation i villahaven eller ude i naturen. ${ }^{6}$

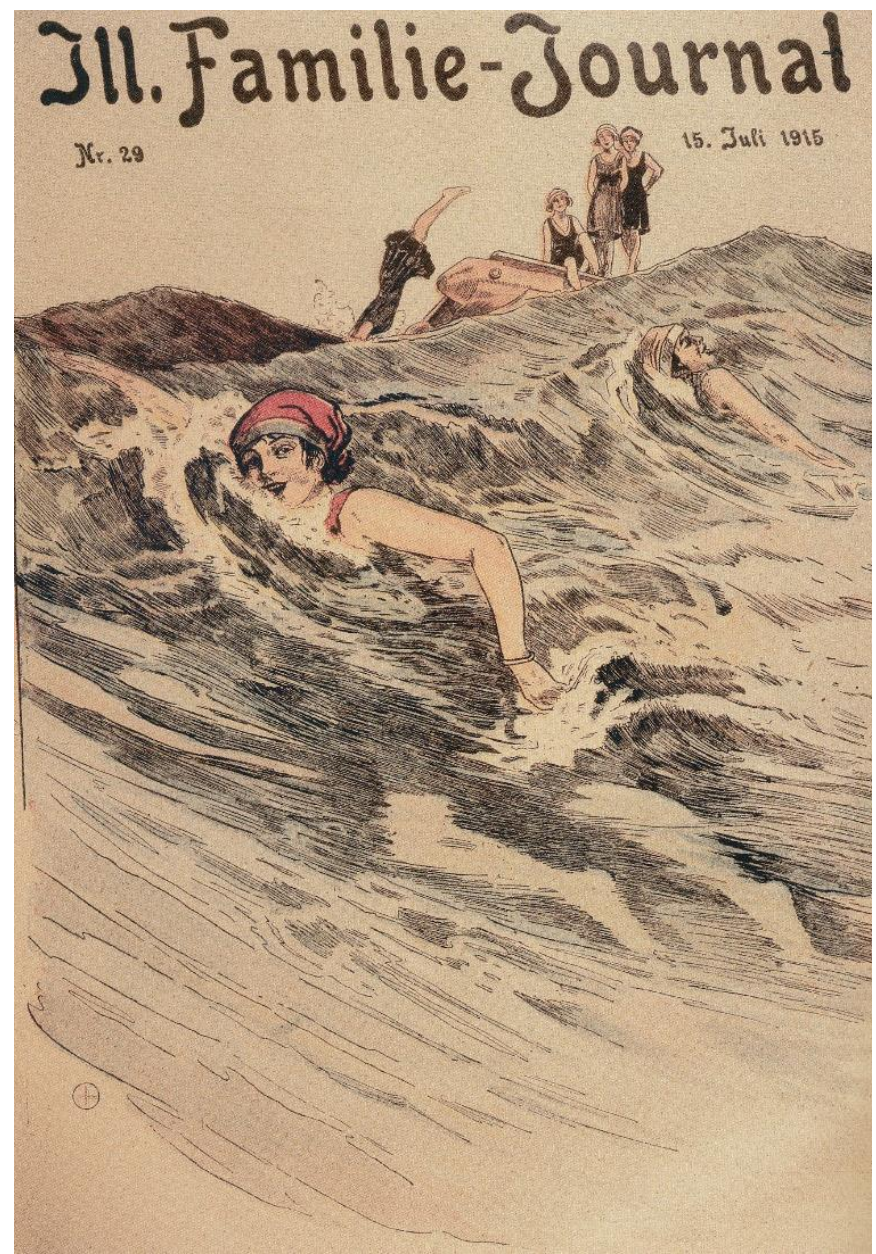

Havbad. En frie- og fritidsfornøjelse for det bedre hovedstadsborgerskab, som havde sommervillaer eller frekventerede tidens badehoteller (IIl. Familie-Journal, juli 1915). 


\section{Villaen på landet}

En mulighed for solbrændthed og nydelse af lyset og luften ved kysterne og i den fri natur, som hovedstadsborgerskabet $\mathrm{i}$ årtierne op til og efter århundredskiftet også kunne opnå ved at flytte kernefamiliens villalivsform fra hovedstaden og ud på landet. Til først sommervillaer ogpalæer ved Nordsjællands kystområder eller siden også så langt væk som eksklusive feriesteder i provinsen som Skagen, Løkken, Lønstrup, Blokhus og Rømø. Sociale enklaver for overklassen, hvor sommerlivet kunne udleves med ligestillede uanset om, man kom fra stedlige sommervillaer eller var indlogeret for en længere periode på badehoteller eller kurbadeanstalter.

\section{Langs Strandvejen}

Selv om det kystnære Østerbro tidligt fik mondæne vilakvarterer i den indre del og senere ved Ryvangen, blev ingen af disse anvendt til sommerbeboelse. Med disse kvarter og med først industri- og arbejderkvarterer og siden kvarterer med etagebyggeri med lejligheder af forskellige størrelse og art og betydelige havne- og industrikvarterer, fik Østerbro op gennem den sidste del af det 19. århundrede og frem til tiden omkring første verdenskrig i det væsentligste samme karakter som de øvrige københavnske brokvarterer. ${ }^{7}$

Fra Hellerup i Gentofte Sognekommune og langs Strandvejen nordover fik bebyggelsen og den sociale beboersammensætning derimod på sammen tid en anden karakter. Ud over små fiskerlejer og nogle af merkantilismens manufakturer, havde aristokratiet allerede fra slutningen af 1700-tallet og ind i det nye århundrede placeret et større antal landsteder langs den attraktive Øresundkyst med vidtstrakte udsigter over sundet til Skåne, og årtierne op mod og efter århundredskiftet fulgte industrikapitalismens borgerskab efter. I en stribe langs kystlinjen helt op til Nivå Bugten opstod således et smalt bybælte, der kom til at omfatte ikke blot badehoteller og kurbadeanstalter, men også meget store og herskabelige villaer udlagt på store grunde eller nærmest palæagtige landsteder med omgivende parkanlæg. Bebyggelser, der alle tidligt forsynedes med tidens faciliteter, først rindende vand og gas og siden elektricitet og telefon, og som fremstod i en nærmest grotesk kontrast til de industri- og arbejderkvarterer og andre senere kvarter med etagebyggeri, som hovedstadens arbejderklasse og lavere funktionærlag var henvist til.

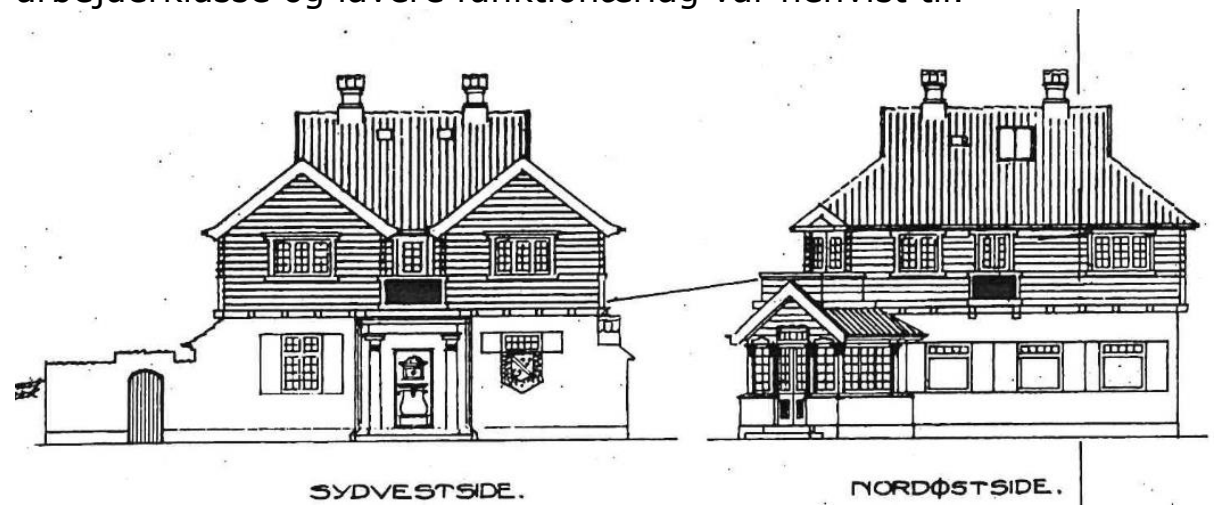

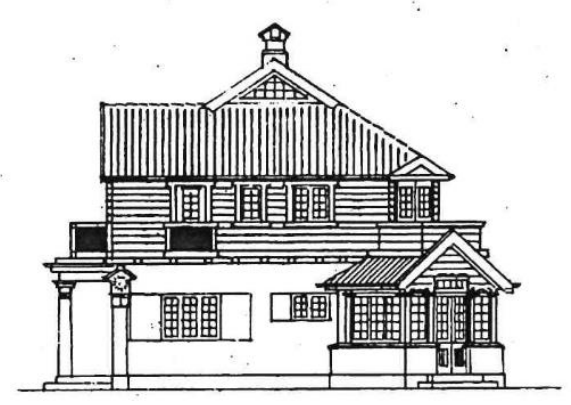

SYDASTSIDE.

Blandt de enorme sommervillaer langs Nordre Strandvej mellem Helsingør-Hornbæk blev sommervillaen "Ørnæs" fra 1916 med en grundmuret stueetage og en førstesal udført som en mægtig trækonstruktion (Helsingør Kommunes Byggesagsarkiv)

I første omgang opførtes disse villaer og landssteder med henblik på sommerophold for hovedstades absolutte overklasse, men allerede i den sidste del af det 19. århundrede overgik de fleste i bæltet fra Hellerup til Klampenborg til helårsbeboelse. Med den samtidige opførelse af tilsvarende ejendomme på de tilbageværende ledige grunde langs strandvejen og i et stadig bredere område vest for, kom Gentofte Sognekommune allerede ved århundredskiftet til omfattede meget betydelige forstadsområder. En forstadsomdannelse med nu helårsbeboelser i ældre sommervillaer og-palæer og nyt tilsvarende villabyggeri, der med forlængelsen af Kystbanen fra Klampenborg til Helsingør i 1897 kom til at forsætte langs Strandvejen til Nivå 
Bugt, og som i Vedbæk og særlig i Rungsted i mellemkrigstiden og 40'erne kom til at brede sig længere vest for vejlinjen og Kystbanen. Da tidens mest moderne forsyningslinjer- og former tidligt var blevet udlagt til de tidligere områder med sommervillaer og- palæer, og disse samtidig havde fået gode privatanlagte lokalveje, der senere blev kloakeret, belastede overgangen til forstad her ikke de stedlige sognekommuner. Tværtimod bidrog helårsbeboernes meget høje indkomster til en meget betydelig forbedring kommunernes skattegrundlag. ${ }^{8}$

Selv om Nivå Bugt og dets marine forland af store mose- og engområde satte en naturgiven barrierer for samme udbredelse af hovedstadsborgerskabets sommervilla- og palæbyggeri, kom det dog til at udgøre et betydeligt islæt i Strandvejsbæltet fra Humlebæk og nordover, hvor fiskerlejer og prætentiøse sommer- og villabebyggelser prægede billedet frem til Tibberup syd for Helsingør. Herfra bredte et bælte af store villaer, primært for Helsingørs borgerskab, i de første årtier af det 20. århundrede sig frem til den gamle købstads yderdistrikter og brokvarter. Et helt tilsvarende bebyggelsesmønster, med villakvarteret Marielyst, kom til at kendetegne Helsingørs yderdistrikt pă det første stykke af Kattegatkysten vest for byen. ${ }^{9}$

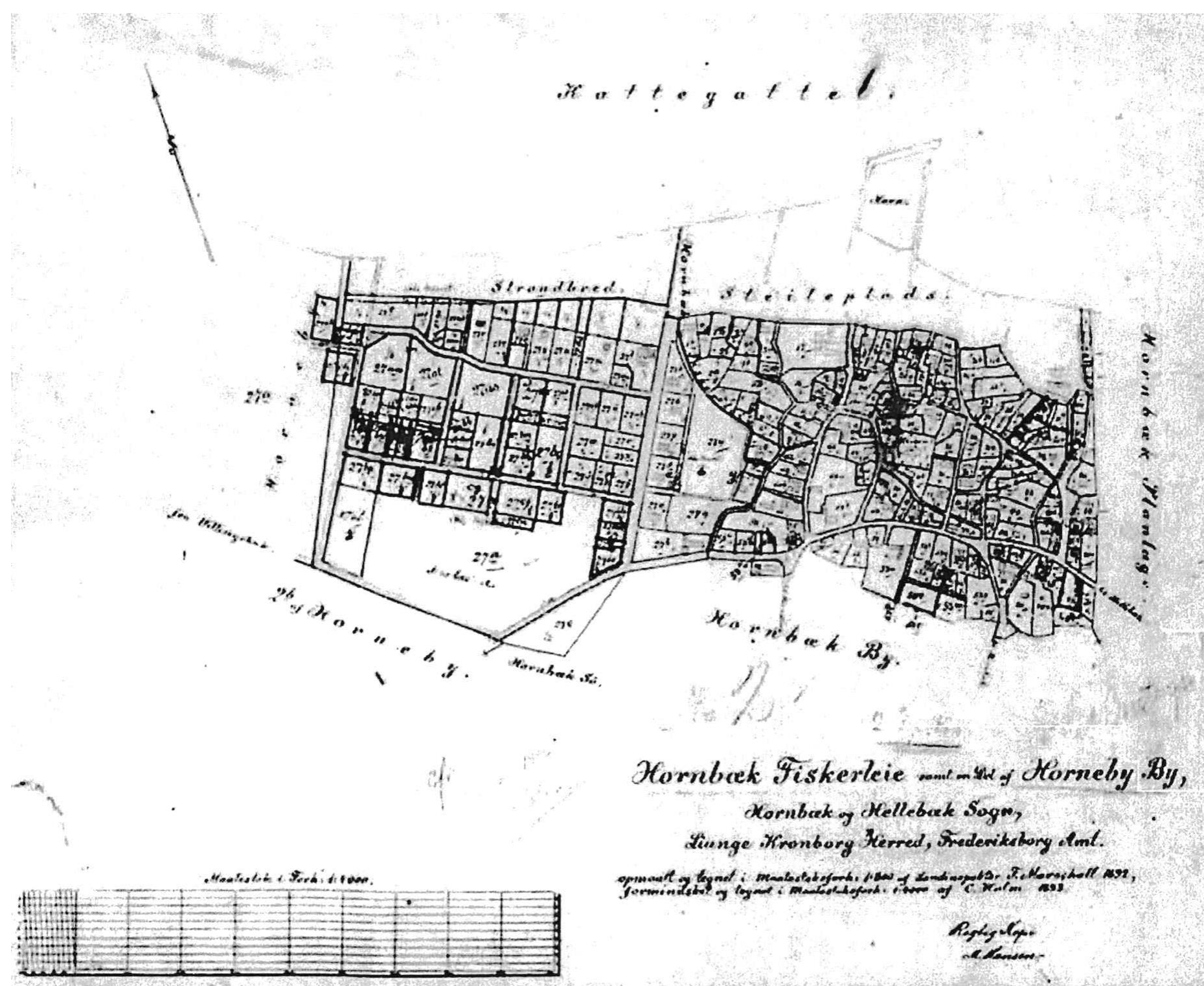

Hornbæk. Udstykningsplan for omradet med sommervillaer, til venstre, og fiskerlejet Hornbæk, til højre. (Matrikelkort 1893-1906, Kort- og Matrikelstyrelsen) 


\section{Kattegatkysten}

Allerede i 1860- og 70'erne havde billedkunstnere som Viggo Johansen, P.S. Krøyer, Holger Rose og Holger Drachmann søgt ud til uspolerede landskaber og kyster, hvor de hos de lokale lejede hus eller rum for der at det nyde det simple liv og udleve de kunstneriske evner. På Kattegatkysten tiltrak navnlig Hornbæk og senere Gilleleje, Tisvildeleje og Rørvig dette kunstnersegment, og efterhånden søgte det bedre borgerskab fra hovedstaden ud til de kunstneriske miljøer og naturens scenerier ved kysten. I første omgang som sommerlejere i huse eller værelser i lokale fiskerhuse og siden på hoteller og pensionater.

Fra slutningen af det 19. århundrede og frem til tiden omkring første verdenskrig opførtes godt og vel 500 sommervillaer og- palæer i bæltet langs Strandvejen. Med den eksisterende bebyggelse og den samtidige omdannelses til forstad i bæltets sydlige del indsnævredes her efterhånnden mulighederne for yderlige sommervillabyggeri for hovedstadsoverklassen. Køge Bugt lå ganske vist relativt tæt ved hovedstaden, men var trafikalt isoleret, og havde uden sammenligning ikke de samme landskabelige attraktioner som det nordligste Nordsjælland. Med de vidstrakte åbne kysttrækninger med gode strande, kunstnermiljøer og enklaver for det ferierende hovedstadsborgerskab, som Kattegatkysten kunne byde på, blev det videre sommervillabyggeri derfor fra tiden omkring århundredskiftet i stadig større omfang lokaliseret til kyslinjen vest for Helsingør.

Den oprindelige bymæssige bebyggelser omfattede her fiskerlejerne Ålsgårde, Boderne, Ellekilde samt Hellebæk, og til området var der udlagt tidens bedst tænkelige trafiklinjer. ${ }^{10} \mathrm{I}$ form af dels Nordre Strandvej langs Kattegatkysten fra Helsingør og gode sognekommunale sideveje med forbindelse til de amtskommunale landeveje, som førte ind til hovedstaden, dels en sidebane, der fra Helsingør fra 1906 fulgte kystlinjen til Hornbæk, som med sin betydelig fiskerihavn og som stationsby allerede i 1911 havde opnået en befolkning på 846 indbyggere.

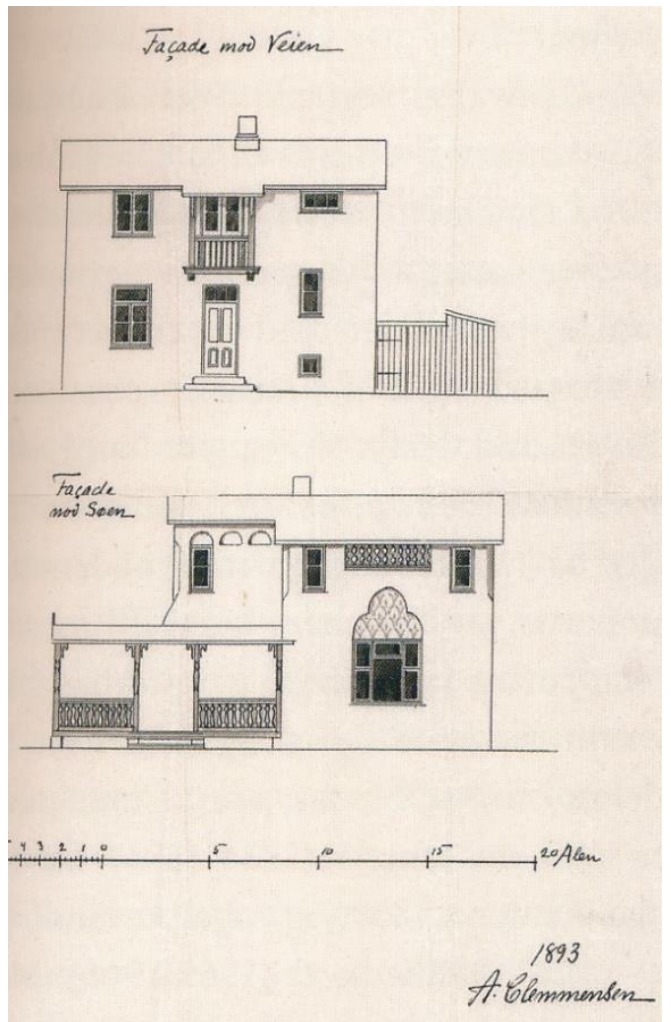

Tegning til Harald Plockross egen italiensk inspirerede sommervilla på Kystvej i Hornbæk. Plockross fik opført et mindre antal tilsvarende sommerhus, som han siden frasolgte til andre landliggere fra hovedstaden. (Samlingen af arkitekturtegninger, Danmarks Kunstbibliotek) 
Med disse gunstige forudsætninger udstykkedes fra villakvarteret Marielyst i Helsingør og til fiskelejet Hornbæk fra 1902 de friarealer, der lå uden for de stedlige plantager og bebyggelser. På de store og ganske isolerede parceller opførtes på begge sider af Nordre Strandvej i tiden op til første verdenskrig 155 meget store sommervillaer med haver ned til og udsigter over Kattegatkysten. Mens sommervillabæltet langs Nordre Strandvej fik en langstrakt og mere spredt bebyggelseskarakter, var der nærmest ved et tilfælde få år før lige vest for Hornbæk blevet skabt forudsætning for et større, kompakt, sammenhængende og egentligt sommervillaområde; landets første af sin art.
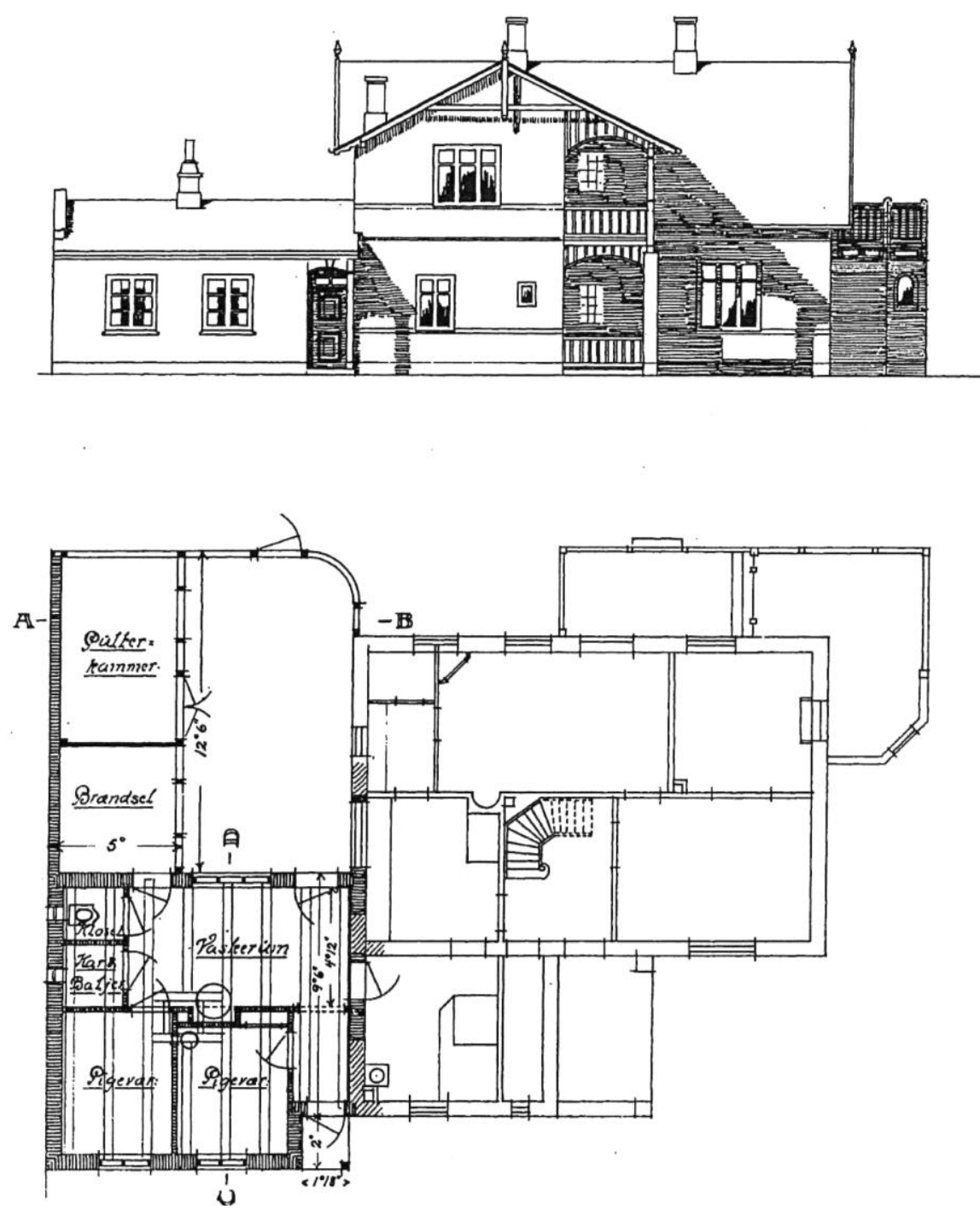

Efter Plockross' byggeri førtes en række andre store sommervillaer bl.a. "Villa Strand", der allerede i 1915 måtte udvides med de yderligere pigeværelser og det større vanskelrum, som ses til vestre (Helsingør Kommunes Byggesagsarkiv)

Området blev i 1891 udbudt til salg, men da det var lyngbevokset og ufrugtbart og dermed ikke havde lokal interesse, afkøbtes det året efter af den københavnske overretssagfører Harald Plockross, der udstykkede det til sommervillaer. Sagføreren fik tegnet nogle italiensk inspirerede villaer og sammen med det efterfølgende byggeri, var området mellem Hornbæk by, Trouville Vej, Nordre Strandvej og Kattegatkysten inden første verdenskrig blevet bebygget med 55 meget store og herskabelig sommervillaer. Alle med et stort antal stuer og sove- og gæsteværelser, værelser til tjenestepiger, storkøkkener, anretterværelser, verandaer, 
altaner, garager og udstyret med moderne faciliteter som f.eks. bad og wc, varmeanlæg, elektricitet og indlagt vand og gas. Rammer, der svarede til vintervillaerne i de ældre villakvarterer på indre Frederiksberg og Østerbro og de nyere i Ryvangen, og som muliggjorde, at sommer- og ferieperioderne på "landet" kunne leves på samme måde som i vintervillaen i hovedstaden. Livsstilen og omgangskredsen kunne således, uden videre kontakt med de lokale, opretholdes og formede sig som samkvem med ligestillede og- sindede landliggere i sommervillabyen eller fra Hornbæks badehotel og pensionater samtidig med, at den indlagte telefonlinje sikrede kontakten til forretningsforbindelser, familie og venner i byen. ${ }^{11}$

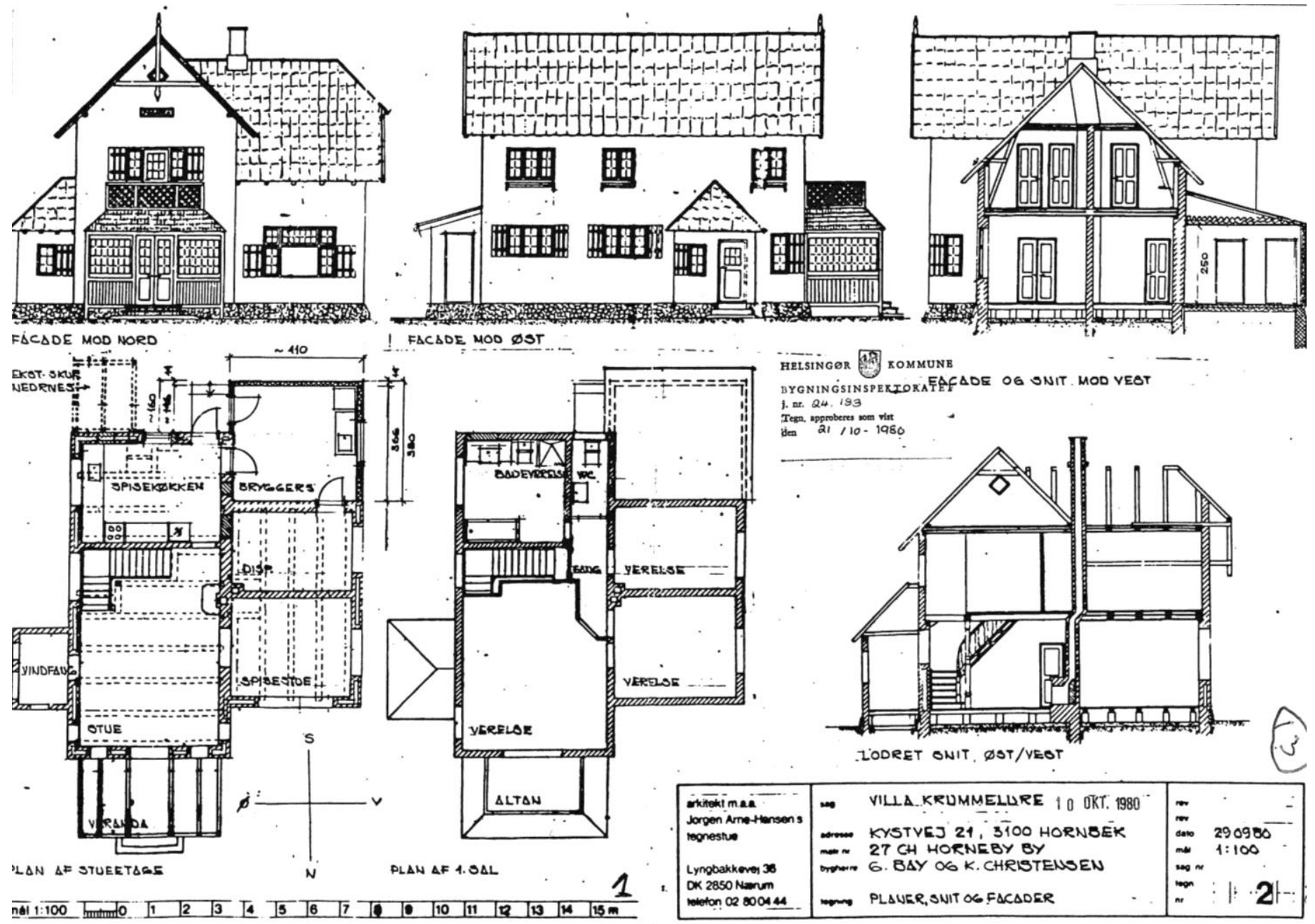

Byggeriet af sommervillaer vest for Hornbæk fiskerleje forsatte efter arhundredskiftet, bl.a. med "Villa Krummelure" (Helsingør Kommunes Byggesagsarkiv).

\section{Planlagt og velordnet - på trods}

Som følge af de liberalistiske dogmer, der op gennem den sidste halvdel af det af det 19. århundrede og i de første årtier efter århundredskiftet lå bag både den residuale natvægterstat og efterfølgende socialhjælpsstat, rummede hovedstads- og købstadskommunernes bygningslove eller sognekommunernes lov om brandpoliti på landet alene minimumbestemmelser for bebyggelsens omfang og højde på de enkelte parceller og ud fra brandtekniske og hygiejniske hensyn regler for bygningernes konstruktion og indretning; jf. tekstboks.

Kommunerne var således ikke udruste med lovsfæstede beføjelser til at gennemføre byplanlægning eller nærmere at regulere bebyggelser i det åbne land. Fordeling af bebyggelsesarter, byers spredning og anvendelsen og bebyggelsen af landdistrikterne blev 
dermed overladt de frie markedskræfters planløshed, hvorved bebyggelser lokaliseredes på en sådan måde, at de enten gav størst mulig afkast ved leje eller salg af beboelsesbygninger, medførte lavest mulige omkostninger for erhvervsbygninger eller fik den mest attraktive beliggenhed for helår- og sommervillaer.

Da netop Øresund og Kattegats attraktive kyst udgjorde en særlig lokaliseringsfaktor for tidens sommervillaer, blev konsekvensen, at disse lagdes helt ud til kystlinjen, og at den fik karakter af meget langstrakte sommervillabælter. En for almenheden social ekskluderende afskæring af adgang til Øresunds og Kattegats kyster over en mere end $50 \mathrm{~km}$ lang strækning fra Hellerup i syd til Hornbæk mod nord og en samtidig ødelæggelse af et hidtil uberørt, vidtstrakt, åbnet og højklasset kystlandskab.

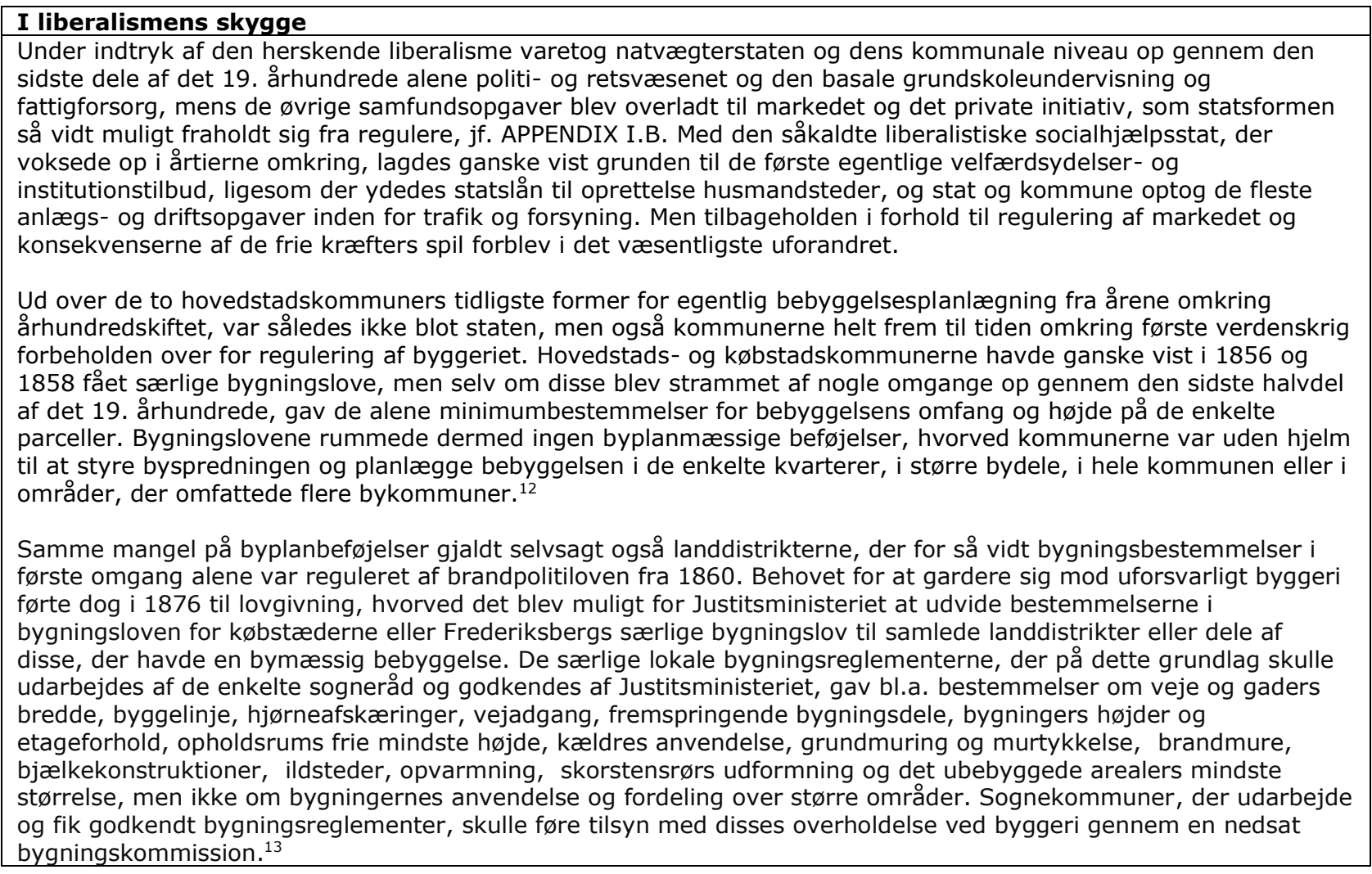

I forhold til den planløse og tætte overbebyggelse, der i den sidste halvdel af det 19. århundrede kom til at kendetegne de indre københavnske broer og frederiksbergske bykvarterer, og som først blev imødegået af en strammere kommunal planlægning af nye kvarterer fra omkring århundredeskiftet, kom overklassens sommervillabyerne langs Strandvejen og langs og ved Kattegatkysten på samme tid til at fremstå ganske planlagte og velordnede. Helt som borgerskabets villakvarterer på dele af Østerbro og Frederiksberg og det på trods af, at de sognekommuner, sommervillaerne var beliggende i, ligesom hovedstads- og købstadskommunerne, havde stærkt begrænsede beføjelser til at regulere og planlægge bebyggelsen.

At bebyggelsen i disse sommervillabælter og i det kompakt bebyggede sommervillaområde vest for Hornbæk, trods afspærringen og ødelæggelsen af kystlinjen, alligevel fik et regelmæssigt vejforløb og en rimelig planlagt karakter, var udtryk for sommervillaejernes egeninteresse i, at udmatrikulering, vejanlæg og bebyggelse, ligesom i deres villakvarterer i hovedstaden, gennemførtes under velordnede forhold. Samme egeninteresse i at opføre store velbyggede og - udstyrede sommervillaer bevirkede samtidig, at de enkelte bygninger langt oversteg de minimumskrav, der var nedlagt i de bygningsreglementer, som samtlige af de 
sognekommuner, der omfattede Strandvejens og Nordre Strandvejens kystlinje, fik udarbejdet i gennem perioden. ${ }^{14}$ 


\section{Delkonklusion}

Mellem- og efterkrigstidens sommerhusbyer i hovedstadsmetropolens åbne land har en lang forhistorie. Måske helt tilbage til antikkens Romerrige, hvor Roms overklasse søgte ud til sommervillaer uden for imperiets hovedstad, men i hvert fald fra en gang i det 17. århundrede, hvor København begyndte at udvikle sig til en storby af europæiske dimensioner, og hvorfra først aristokratiet og siden højborgerskabet, som i andre af Europas storbyer, flyttede for om sommeren at udleve livet på sommerslotte- og landsteder.

Kombinationen af byens vokseværk og fortætning, en arbejdsfri del af livet og økonomiske ressourcer blev drivkraften bag denne eksklusive landliggerbosætning. En drivkraft, der forstærkedes med industrialismens voldsomme urbanisering fra midten det 19. århundrede og frem til tiden omkring første verdenskrig, hvor det blev tidens nye overklasse, der fik det $\varnothing$ konomiske grundlag for og den arbejdsfrie tid til at søge ud af den fremvoksende hovedstadsmetropol og ud til stadig større sommervillabyer ved metropoloplandets mest attraktive kystområder.

\section{Sommerslotte- og landsteder}

Helt op til den første del af det 20. århundrede var alene samfundets øverste lag begunstiget med fritid og ferie, og havde økonomiske muligheder for at omsætte dette gode til sommerophold uden for hovedstaden. Fra en gang i 1600-tallet rykkede kongefamilien og hoffet ud af det stadig mere tætbebyggede og fæstningsindespærrede København til sommerslotte i hovedstadsoplandet. Først til Frederiksborg Slot i Hillerød, senere Frederiksberg Slot lige uden for voldene og siden til de nyere nordsjællandske slotte i Hørsholm og Fredensborg. Fra slutningen af 1700-tallet og ind i den første halvdel af det følgende århundrede fulgte det mest velstående borgerskab og provinsgodsejere med københavnske palæer efter og opførte et større antal sommerlandsteder i hovedstadens nærmeste nordlige opland og på Frederiksberg.

\section{Sommervillabyer}

Med industrikapitalismen og den ledsagende urbaniseringsproces sprængte København sig med en befolkning på 130.000 indbyggere i midten af det 19. århundrede ud af sin befæstning, og inden første verdenskrig var de uden om liggende bro- og voldkvarterer helt udbygget, ligesom Frederiksberg havde forvandlet sig fra et landsogn til en storby, der var fuldt integreret i den udvidede hovedstad omfattende omkring en halv mio. indbyggere. På samme tid blev fabrikanter, grosserer, vekselerer, skibsreddere, storentreprenører, ledede privat og offentligt ansætte embedsmænd hovedstadens nye overklasse, mens mindre selvstændige og øvrige funktionærer og fag- og ufaglærte arbejdere blev en hastigt voksende mellem- og underklasse.

Udover voldsomme forskelle i indkomst- og arbejdsforhold og bolig- og levevilkår afspejledes industrisamfundets klasseforskelle sig i adgangen til fritid og ferie. Et gode, som helt frem til et godt stykke efter århundredskiftet alene overklassen var begunstiget med, og som den ud, over selskabelighed, deltagelse i hovedstadens kulturliv eller i det idræt- og friluftsliv, der i første omgang var forbeholdt de mest velbjærgede, omsatte til et kærnefamilieliv i en villa. En af tidens nye boligformer, som både afspejlede og blev den optimale ramme for den fra industrialismens produktions- og arbejdsliv isolerede kærnefamilie, og som samtidig blev en modreaktion i forhold urbanismens fortættede byrum og dermed udtryk for tidens trend: Et liv i eller omgivet af det fri med frisk luft og lys. En boligform, som blev normdannede for de filantropiske og senere kooperative byggeselskaber, som overklassen op gennem den sidste halvdel af det 19. århundrede stod bag for at bedre arbejderklassens bolig- og levevilkår, og som omfattede rækkehuslignede bebyggelser med omliggende haver og grønne områder. 
Men villaen blev også den form, som overklassen overførte som boligramme for sommerlandliggerlivet i den fremvoksende hovedstadsmetropols opland. Først i form af monstrøse sommervillaer, der bredte sig i smalt bybælte op langs Øresundskysten fra Hellerup til syd for Helsingør. Et sommervillabælte, som i den sydlige del kom til at blive en katalysator for forstadsdannelserne mellem Hellerup og Runsted, men som vest for Helsingør efterhånden bredte sig videre langs Kattegatkysten til Hornbæk, hvor der vest for fikserlejet fra 1893 og i de følgende årtier opstod en egentlig sommervillaby. Den første af sin art i landet og endda af en ganske planlagt karakter, da sommervillaejerne af egeninteresse ønskede ordnede forhold for så vidt vejudlæg, bebyggelse, forsyning med vand, gas og elektricitet og spildevandsafledning. 


\section{Noter:}

Forkortelser:

Lovt.: Lovtidende

\footnotetext{
${ }^{1}$ Henning Bro: Hovedstadsmetropolen - den dansk byregion, 2020, s. 1219-1221.

2 Bro: Hovedstadsmetropolen - den dansk byregion, 2020, s. 1221-1225.

${ }^{3}$ Bro: Hovedstadsmetropolen - den dansk byregion, 2020, s. 116-128.

${ }^{4}$ Henning Bro: Den grønne hovedstadsmetropol. Det grønne i det røde i Arbejderhistorie, 2, 2014, s. 48-51.

${ }^{5}$ Ditte Wondsyld: Villaen og kernefamilien - villabyggeri i hovedstaden i den anden halvdel af det 19 . århundrede $\mathrm{i}$ Fabrik og Bolig, 2011, s. 43-58. Henning Bro: Boligen mellem natvægterstat og velfærdsstat. Bygge- og boligpolitik i København 1850-1930 [bearbejdet udgave af Ph.d.-afhandling med samme hovedtitel fra 2006], 2008 , s. 80-81.

${ }^{6}$ Ditte Wondsyld: Villaen og kernefamilien - villabyggeri i hovedstaden i den anden halvdel af det 19. århundrede i Fabrik og Bolig, 2011, s. 43-58. Bent Hardervig: Sommerglæder, 2013, s. 10-17, 34-37, 64-87, 114-127, $230-299$. Nan Dahlkild: Fra sommervilla til feriehytter, Byplanhistoriske Noter, nr. 23, 1991, s. 7-23. Sommerhuset - fødsel og opvækst, Byplanhistoriske Noter, 25, 1991, s. 15-25.Karin Lützen: Sommerferiens historie, Kulturstudier, nr. 2011, s. 141-146.

7 Strandvejen - før og nu, bd. 1, 1998, s. 10-19.

8 Strandvejen - før og nu, bd. 1,1998 , s. $20-447$ og bd. 2,1998, s. 21-191.

${ }^{9}$ Strandvejen - før og nu, bd. 2, 1998, s. 217- 343.

${ }^{10}$ Hellebæk udgjorde desuden en af enevældens merkantilistiske industrimanufakturer, der siden 1873 var blevet anvendt som klædefabrik.

${ }_{11}$ Sommerhuset - fødsel og opvækst, Byplanhistoriske Noter, 25, 1991, s. 23-25. J.P. Trap: Danmark, bd. III, 1920, s. 70-71,112-113. Digitale byggesager, Helsingør Kommune:

https://public.filarkiv.dk/217\#e=1\&p=eyI4Ijp7fX0 =

12 Bro: Boligen mellem natvægterstat og velfærdsstat, 2008, s. 92-94 og 117-122.

13 Lov angaaende Tilvejebringelsen af Bygningsreglementer for Landdistrikter af 11. februar 1876, Lovt 1876 , s. 46. ÆEndret ved Lov angaaende yderligere Regler for Tilvejebringelsen af Bygningsreglementer for Landdistrikter og Bygningsvedtægter for Købstæderne af 5. december 1894, Lovt 1894, s. 863. Ved denne lov kunne bestemmelserne fra den skærpede frederiksbergske bygningslov fra 1890 helt eller delvist overføres til lokale bygningsreglementer ligesom bestemmelserne fra købstædernes bygningslov fra 1858. I særlige bygningsvedtægter for købstæderne kunne bestemmelserne fra den frederiksbergske bygningslov fra 1890 tillige helt eller delvist overføres. Lov angaaende yderligere Regler for Tilvejebringelsen af Bygningsreglementer for Landdistrikter af 23. april 1915, Lovt 1915 , s. 922-923

${ }^{14}$ Digitale byggesager, Helsingør Kommune: https://public.filarkiv.dk/217\#e=1\&p=eyI4Ijp7fX0 $=$
} 